International Research Journal of Engineering, IT \& Scientific Research
Available online at https://sloap.org/journals/index.php/irjeis/
Vol. 6 No. 5, September 2020, pages: 1-12
ISSN: 2454-2261
https://doi.org/10.21744/irjeis.v6n5.970

\title{
Design Features of the Inca Museum of Culture
}

Iftikhar B. Abbasov a Christina Lissette Sanchez ${ }^{\text {b }}$

Article history:

Submitted: 27 June 2020

Revised: 18 July 2020

Accepted: 9 August 2020

\section{Keywords:}

design concept;

inca culture;

$\log o$;

museum;

mythology;

\begin{abstract}
The paper deals with the development of a design concept for a museum of Inca culture in Ecuador. The current trends in the organization of historical museums in Latin America are presented. An overview of the graphic support of the Latin American museums of culture, archeology, and history is made. The historical foundations of the Museum of Inca culture are presented, the iconography of the Inca civilization of various periods is analyzed. The current state of the museum, the history of its foundation, prerequisites for creating a new brand are described. Associative graphic images for creating a new logo for the museum were considered, corporate colors were substantiated, and components of the brand were developed. This will strengthen the museum's brand and increase its social significance for the popularization of the Inca culture.
\end{abstract}

International research journal of engineering, IT \& scientific research (C) 2020.

This is an open access article under the CC BY-NC-ND license (https://creativecommons.org/licenses/by-nc-nd/4.0/).

\section{Corresponding author:}

Abbasov, I.B.,

Southern Federal University, Engineering Technological Academy, per. Nekrasovskyi, 44, Taganrog, Russia, 347928, Russia

Email address: iftikhar_abbasov@mail.ru

a Southern Federal University, Engineering Technological Academy, per. Nekrasovskyi, 44, Taganrog, Russia, 347928, Russia

b Southern Federal University, Engineering Technological Academy, per. Nekrasovskyi, 44, Taganrog, Russia, 347928, Russia 


\section{Introduction}

When developing the concept of a modern museum space, it is necessary to take into account the main exhibition stands and the surrounding visual information. The design of the interior space of the museum should give the visitor the right direction, create the appropriate atmosphere, and help reveal the content of the exposition. In the modern museum space of Latin America, it is not often possible to find the formulated concept of museums dedicated to the Inca culture. This article examines the cultural aspects of the development of the design concept for the Inca Historical Museum, located in the city of Ibarra, Ecuador. This museum is called the "Museum of the Sun" (Museo del Sol, 2018), now the museum has no attributes of graphic identification, there is no advertising material to popularize historical culture.

\section{Overview of the design of Latin American history museums}

For further analysis, we will consider the graphic support of some modern Latin American museums (Alvarez C., Sanchez, 2002; Stallabrass, 2014; Wu et al., 2002). The National Museum of Anthropology of Mexico, established just over half a century ago, is recognized as one of the most emblematic places for the preservation of the heritage of the indigenous peoples of Mexico. This museum has a definite and concrete graphic identity without losing a cultural essence with a touch of modernism.

The Colombian Cultural History Museum was founded by the Bank of the Republic of Columbia in 1923 with the organization of a small library with documents and books prepared for the study of economic processes. The brand of the museum is very simple, it resembles one side of the coin (Colombian peso), monochrome, this is not the only state museum, the government of this country is trying to preserve its culture in all its corners.

The Larco Museum in Peru is one of the first museums in Latin America to electronically catalog its entire collection and make it available to the community through online catalogs. This archaeological museum, which is housed in an old building, is one of the largest museums in Peru, with not only exhibition halls open to the public but also collections for private visits.

In 1994, the Colombian government approved a project to expand the National Museum, with collections of archeology and ethnography collected on the ground floor of the building with a modern museum assembly. At present, the museum's collections comprise more than 20,000 exhibits, symbols of national history and cultural heritage. As part of their branding, the National Museum of Colombia and its design team strive to link the brand to the museum's exhibits.

The Xul Solar Museum is an institution dedicated to the preservation and popularization of the works of the Argentine artist Alejandro Xul Solar and seeks to develop and promote culture in its various aspects. The museum was established in 1986 by Mikael Cadenas in the late 1930s. The same space functions as a cultural center, hosting cultural events and contemporary exhibitions.

According to the analysis, the museums of Latin America have a lot in common in the graphic part, as well as in the part of the space, since most of the museums are state-owned. However, some museums are privately owned, which have their criteria in terms of the brand. When developing a corporate identity for historical museums, care should be taken not to interfere with the structural part of the museum building.

The museums located in the northern part of the American continent are mainly museums in Mexico, as Mexico is one of the richest countries in North America. They have the culture of the Aztecs, Maya, they are trying to save their traditions and culture by restoring their iconography. However, Central American museums are more reserved, although they are also trying to save their folklore. South American museums share much of the history, as much of today's territory was dominated by the Inca Empire, which was one of the predominant cultures before the Spanish conquest. Based on traditions, colors, customs, clothing, the iconography of the Inca culture was analyzed. Hieroglyphs, pictograms or graphic symbols existed then and are present in the daily life of the indigenous people. Signs, symbols, colors of the Inca culture are used in clothing design, which is most obvious when visiting cities that still preserve this culture. The methodological basis of this work is also based on the research of this topic by the following Latin American scientists: Mario Brito, Osvaldo Guaman Romero, Isaac Bayon, whose works are devoted to the Inca iconography of Ecuador and its application in folklore (Carlos, 2004; Brito Mario, 2013; Salomons et al., 1993). 


\section{Historical foundations of the Inca culture museum}

In the Encyclopedia of Ecuadorian History, the Inca is defined as American Aborigines who, before the arrival of the Spaniards, lived in western South America, from present-day Ecuador to Chile and north of Argentina, with its capital in Cuzco (Inca Culture, 2013; Huang \& Benyoucef, 2013). In the 11th century, the Incas were a Quechua tribe living in the Cuzco region, in particular in Peru. Those who ruled the empire were called Incas, they were considered children of God and were supported by the military aristocracy. The Inca Empire or Tahuantinsuyo was founded in the 12th century by the Quechua tribe from the areas of Lake Titicaca, between Peru and Bolivia (Inca Culture, 2013; Zuidema, 1986). In the 12th century, they began to form a vast and powerful empire, dominated by several geographic areas. In a historical process that lasted until the 15th century, the strength and supremacy of the Incas led to the empire reaching its maximum development, along with the important Mayan and Aztec civilizations before the Spanish period. The empire was created by Manco Capac, and later ruled by Pachacuti Yupanki, and later by his sons Tupac-Yupanka and Guayna-Capac, who increased the empire with new conquests.

According to Jorge Salvador, "their distant origins are shrouded in mystery and almost nothing is known about them. It is known that they spoke the Quechua language, the last borders of their possession, both the Incas and Quechua, were two rivers that descend from the Andes to turn into a southern tributary of the Amazon " (Inca Culture, 2013; Carelli et al., 2004).

The Tahuantinsuyo Empire, during its splendor period, reached almost two million square kilometers and extended to the present territories of Ecuador, Peru, and Bolivia, as well as northern Chile and the Andean regions of Argentina. Its population reached ten million inhabitants, according to the Incas, Tahuantinsuyo covered all four parts of the world: Chinchansuyo - north; Colasuyo - south; Antisuyo - east; and Contisuyo - west.

The Inca Empire was theocratic and autocratic since it completely obeyed the will of the Inca sovereign, who was considered God, the son of the Sun. His reign was hereditary, chosen by elites, high priests, and military leaders, among the best of his representatives. Inca art excelled in dance, music, poetry, and ceramics; and its architecture, although simple, was very solid, as is demonstrated in ancient buildings that still exist in Peru, such as Machu Pichu and Ingapirca Ruins in Ecuador. The Inca Empire came to an end when the Spanish conquerors killed the last Inca emperor, Atahualpa, on July 26, 1533.

\section{Inca mythology}

In Inca mythology and religious belief system, Inti was the sun god and one of the most important deities of the Inca pantheon. As a solar god, Inti is associated with agriculture, as the sun as a celestial body provides the fields with the light and heat needed to grow crops. Thus, Inti was a god very revered by the farmers of the Inca culture (Fig. 1, left). It was believed that Inti was the son of Viracocha and his wife - mom Kocha.
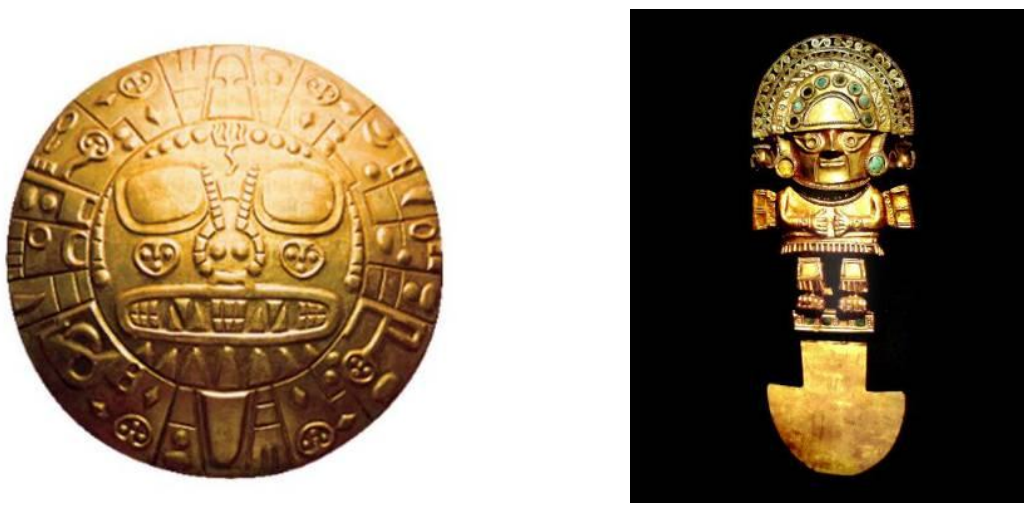

Figure 1. Sun God Inti and God Viracocha

The Incas considered Viracocha to be their supreme deity, who was the creator of the universe, while mother Kocha was the goddess of the sea. As the creator of everything, Viracocha (Fig. 1, right) was the most important god of the

Abbasov, I., \& Sanchez, C. L. (2020). Design features of the Inca museum of culture. International Research Journal of Engineering, IT \& Scientific Research, 6(5), 1-12. https://doi.org/10.21744/irjeis.v6n5.970 
Incas, with his son Inti ranked second after his father. In a certain version of the Inca legend, Viracocha had two daughters besides the son of Inti: Pachamama and Mama Killa. The first is revered as the goddess of the earth, and the second - the goddess of the moon (Zuidema, 1986; Jorge, 2005; Sauermann \& Roach, 2013).

They excelled in art and architecture, built beautiful cities: Cusco, Machu Picchu, Huanuco Pampa with beautiful temples: Coricancha, Sakshahuaman. In ceramics, they emphasize their urpus style (jugs), their fabrics are polychrome in color with geometric patterns. Based on the available literary sources, the Inca iconography that existed in different periods of the history of the empire was collected and analyzed (Oswaldo, 2014; Iturralde, Mogrovejo, 2004; Milla, 1990). To create an associative array for a museum of Inca culture, certain graphic forms are required on which this culture is based. These graphic symbols are grouped according to different topics and are shown in Fig. 2-5.

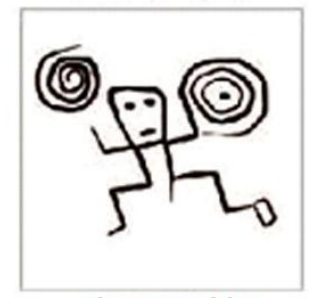

three worlds

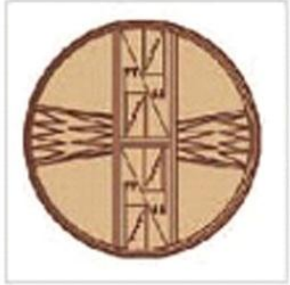

weaving

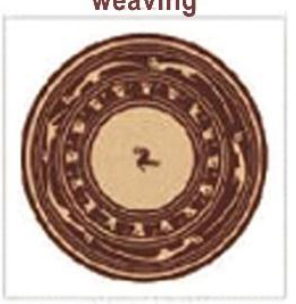

day and night

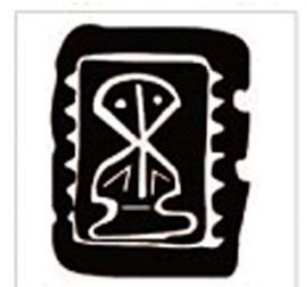

domestication of water

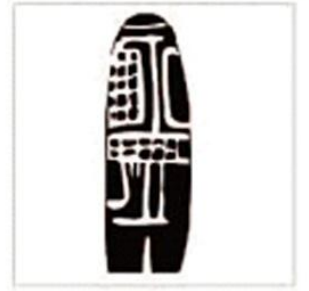

corn

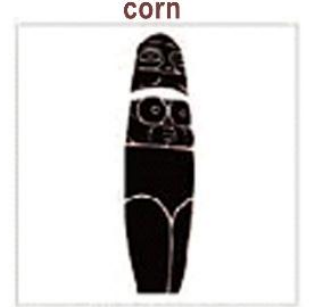

earth creation

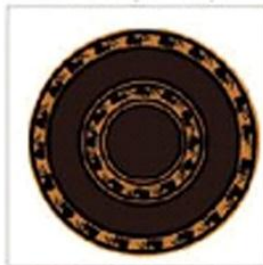

strange alloy

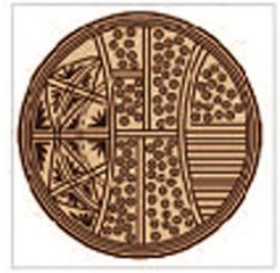

sowing

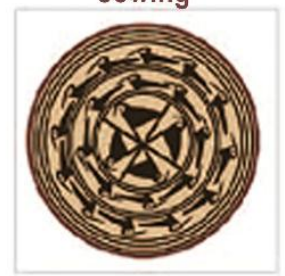

bird migration

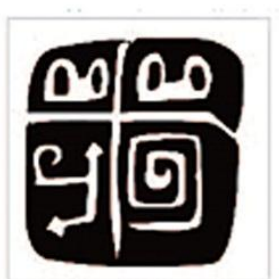

space couple

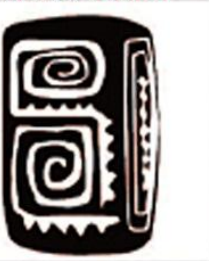

shell

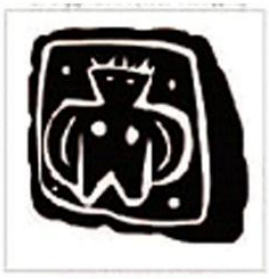

fire woman

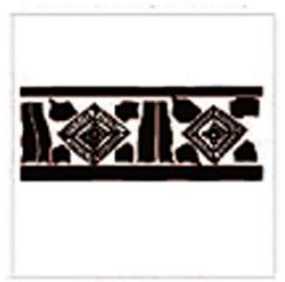

territory

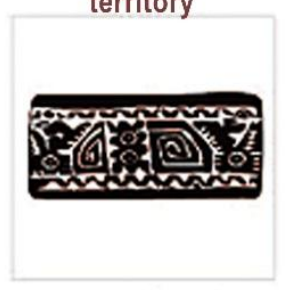

sea and jungle

Figure 2. Inca iconography on the subject of cosmogony and cyclical time 


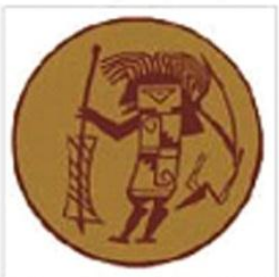

hunter

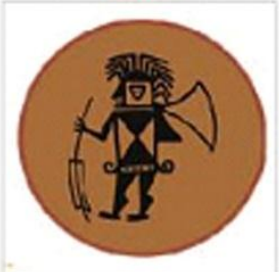

hunting

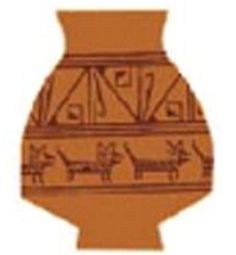

jaguar in motion

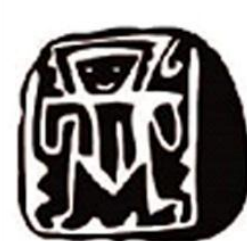

young ruler

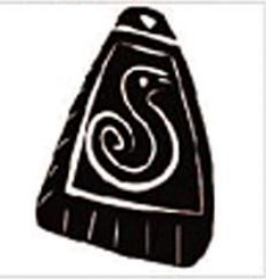

amulet

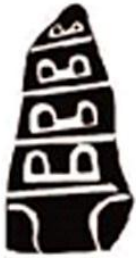

four levels

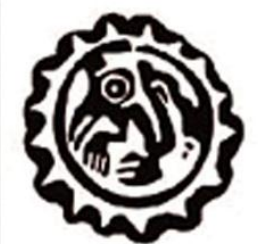

initial flight

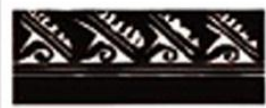

planting

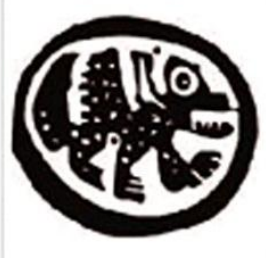

powerful being
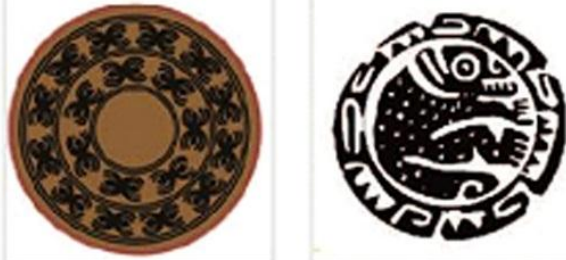

silk

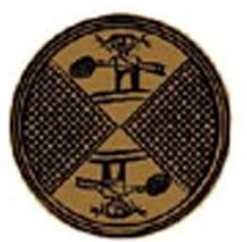

fishing

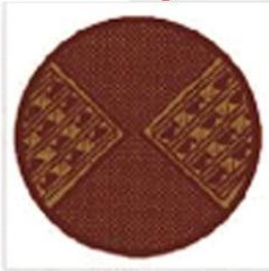

perfect forms guardian of the underworld

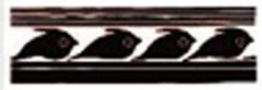

calmness

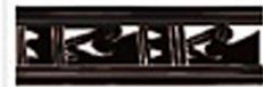

incubation

Figure 3. Inca iconography on nature and hunting

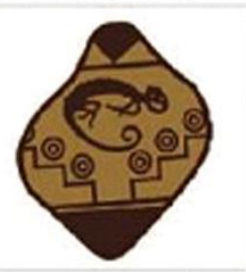

spirit staircase

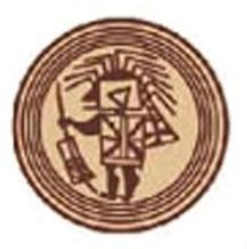

disciple

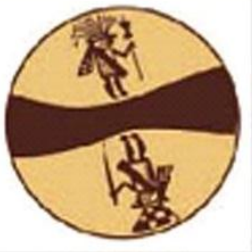

god and shaman

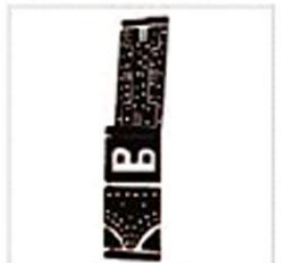

lighting

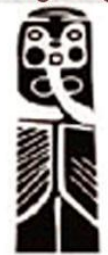

mother valdivia

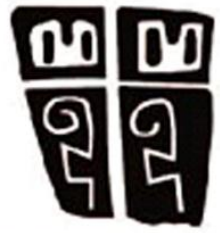

jaguar hunters

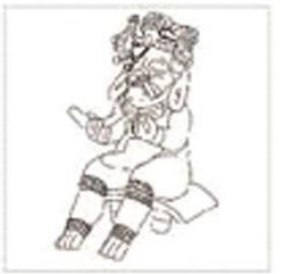

wisdom

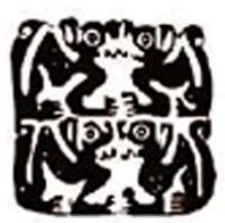

jaguars

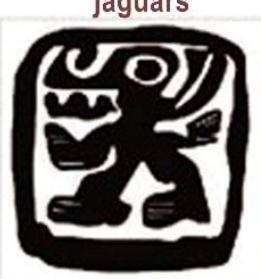

revelation

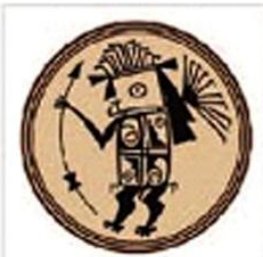

shamanism

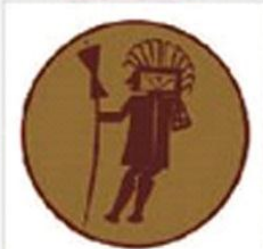

way of the shaman

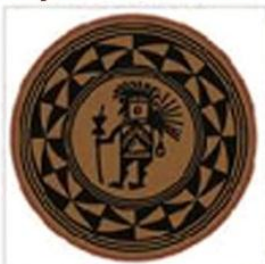

shaman

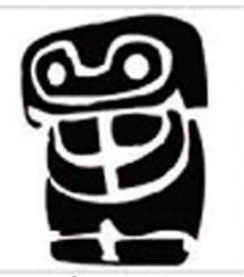

journey

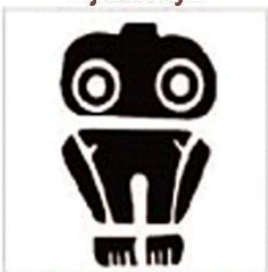

wisdom of the owl

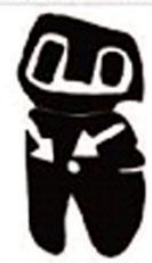

cleaning

Figure 4. Inca iconography on the topic of knowledge and religion

Abbasov, I., \& Sanchez, C. L. (2020). Design features of the Inca museum of culture. International Research Journal of Engineering, IT \& Scientific Research, 6(5), 1-12. https://doi.org/10.21744/irjeis.v6n5.970 


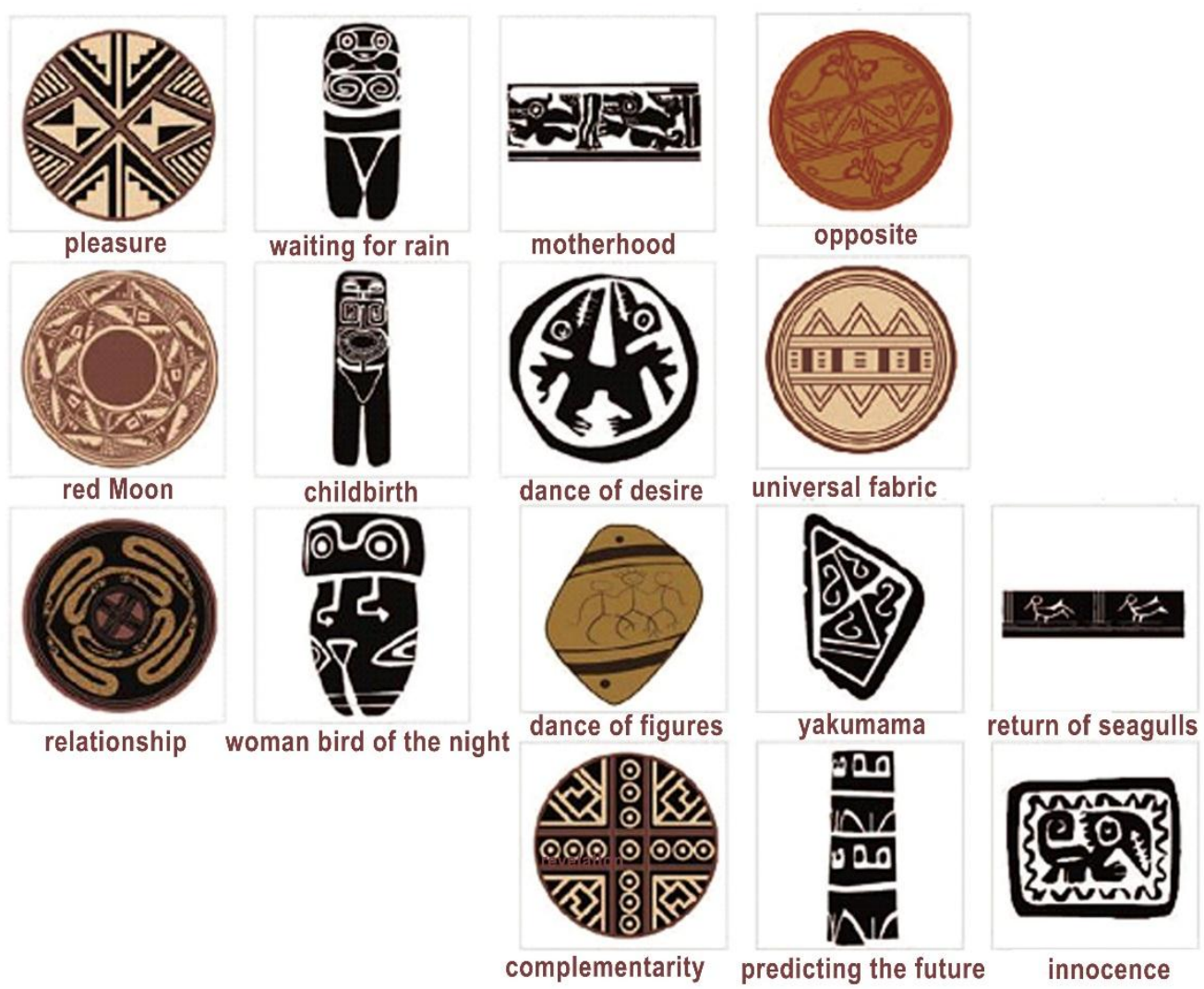

Figure 5. Inca iconography on gender and society

\section{Features of the brand of the Museum of the Sun}

The parish of Caranqui, located $2 \mathrm{~km}$ southeast of Ibarra, is an important settlement of the Inca culture. A large number of archaeological sites were discovered here, which were at risk of extinction. Here was born the ruler Atahualpa, the last Inca emperor, in whose honor the Temple of the Sun was built in 1564. As mentioned earlier, the Museum of the Sun is a replica of the Temple of the Sun, which is located in the city of Cuzco, Peru (Zuidema, 1986; Jorge, 2005). The Temple of the Sun is a building similar to the museum building in the city of Cusco, but on a smaller scale, with ritual rooms inside, shaped like a square (Fig. 6). The Temple of the Sun Museum contains many artifacts that convey history, customs, traditions, objects, help people preserve and remember their history.

The museum displays works from two of the most important pre-Columbian cultures in the Ibarra area. The Karanki culture, which existed between 500 and 1500 AD, and the Inca culture, which dominated these lands after its annexation to Tahuantinsuyo in the early 16th century. Currently, an institution requires a corporate identity, which will include a logo and corporate colors. The task is to emotionally connect the consumer with the created museum brand to achieve the set goals. 

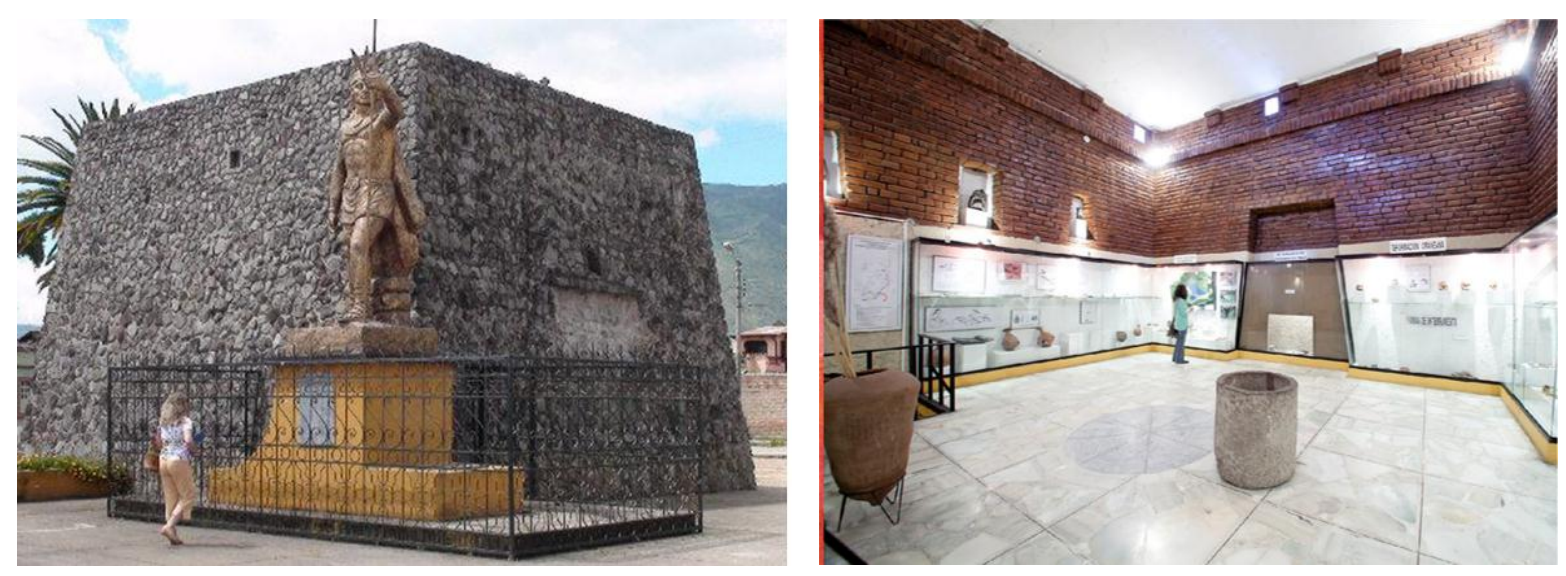

Figure 6. Exterior and interior space of the "Museum of the Sun" (Museo del Sol), Ibarra, Ecuador

When creating a new museum brand, the following special factors should be taken into account (Scott, 2007) originality; color range; the symbolic meaning of flowers; clarity and conciseness of signs; efficiency in attracting visitors. When designing exhibition spaces, their graphic design must be taken into account to reinforce their overall impact. There should also be chromatic, graphic, and symbolic coherence, which will be achieved through the selection of suitable materials for the development of text and graphic bases, the type of font used, the technique used, the color.

Some of these details, such as font, graphics, colors, should be extended to catalogs, tutorials, invitation cards, publications. It is the same with information posters and posters that advertise the exhibition (billboards, banners), then the exhibition will achieve its consistent image (Golovleva, 2005; Dzikevich, 2004). Consider the symbolic interpretation of flowers in Inca culture.

Red is the color of life, blood, disobedience, and courage, it is an intense chase, endless love, the color of Chinchaysuyo, the sign of the northern province of the Tahuantinsuyo Empire.

Orange, one of the scents of fire, represents the maturity of the physical, emotional, mental, and spiritual. Harvest time of what is sown in life, sun deer, maternal growth.

Yellow is the color of corn and the sun, the source of life. Gold, both the being of the ritual and the relationship with Tata Inti (with the father of the Sun), healing energy, wisdom.

Green - territory and life, harmony and healing, reunification with the heart, dance, invigorating energy, this is the dress of Pacha Mama (Mother Earth), food and medicine for the whole world.

Blue is the color of water, sky, the masculine color that brings change and transformation.

Blue - the color of water, feminine color, feminine harmony, time of harmonious energy, reproduction.

Purple is the color of the macrocosm of deities, and the sacred color.

\section{Museum branding development}

The museum was built in 1969 in honor of the last Inca emperor Atahualpa in the form of a truncated pyramid, based on the existing "Temple of the Sun", created in 1564. The first step in brand development is the creation of various options for graphic solutions for the preliminary selection of possible media, which will be selected by the focus group (Airy, 2011). Below are various sketch options for finding a logo based on associations (Figure 7).

Abbasov, I., \& Sanchez, C. L. (2020). Design features of the Inca museum of culture. International Research Journal of Engineering, IT \& Scientific Research, 6(5), 1-12. https://doi.org/10.21744/irjeis.v6n5.970 

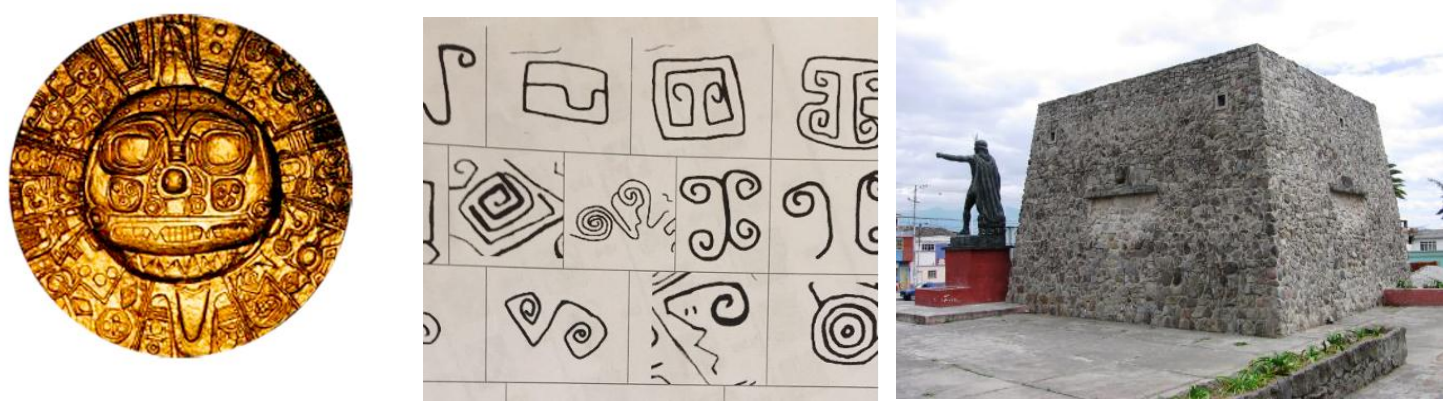

Figure 7. Associative graphic information: Sun God, Inca script, Sun Museum building

\section{Sketch options}

Based on the illustrative material, the following variants of the logo sketches were proposed (Fig. 7-8).

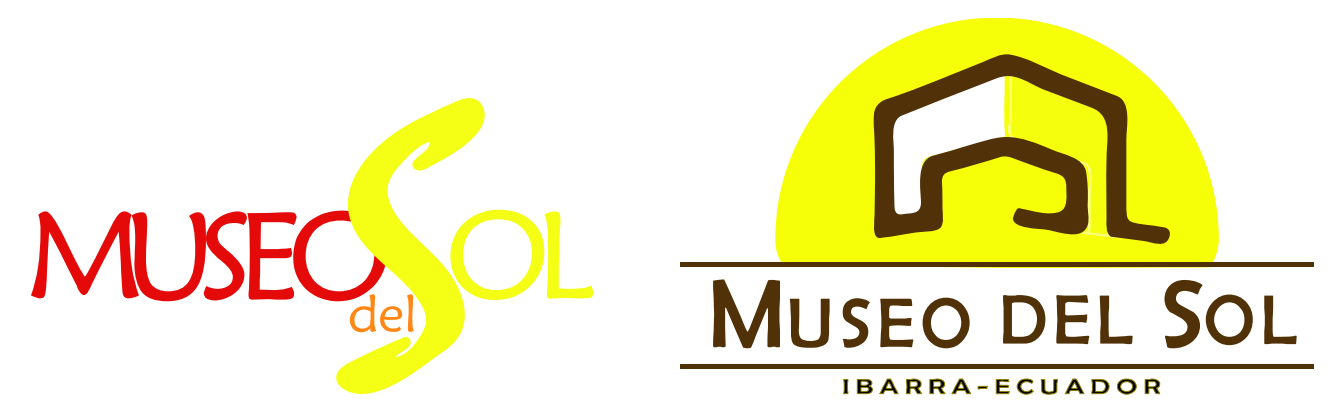

Figure 8. Sketches, first two options
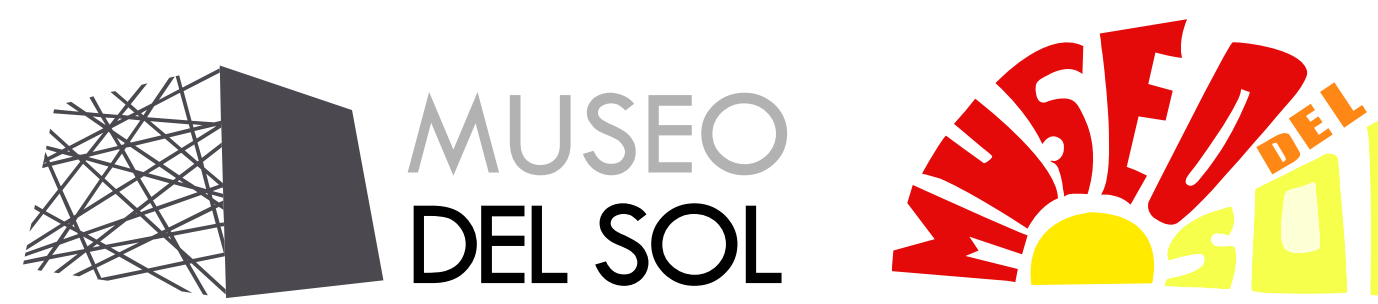

Figure 9. Sketches, third and fourth options

Choosing the final option

As a result of the discussions, the following final version of the logo of the Sun Museum in the city of Ibarra was chosen (Fig. 10).
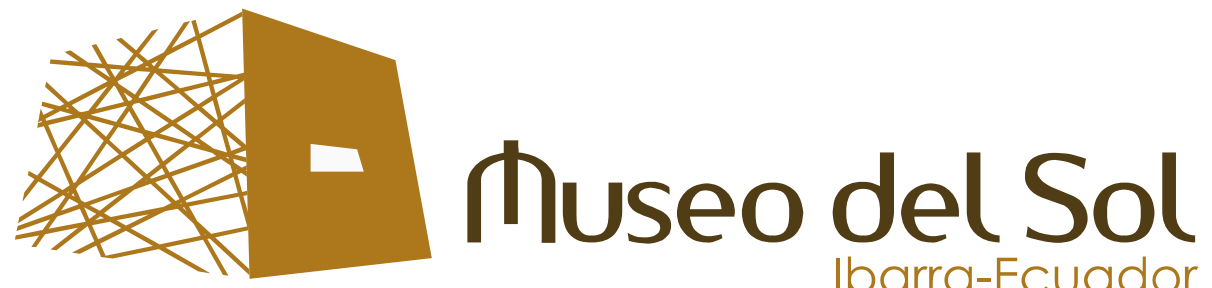

Figure 10. The final version of the logo 


\section{Composition brand}

This part of the project introduces the applications created to strengthen the brand. Today, graphic design is actively and consistently used in museums to develop a global image and identity. That is, like any institution or company, a museum must have a "brand" that identifies it and distinguishes it from others, a corporate chromatic range, a specific set of fonts, that is, a set of elements that define the museum's own identity. The graphic style in general is what determines the identity of the object (Golovleva, 2005). The color tones chosen for the brand correspond to the colors that the Incas used in festivities and rituals, below are the corporate colors (Fig. 11).

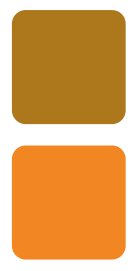

C:9 M:44 Y:91 K:32 R:173 G:119 B:28 AD771C

C:0 M:56 Y:91 K:0 R:240 G:133 B:34 F08522

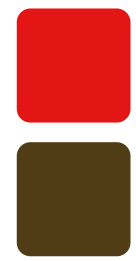

C:0 M:98 Y:99 K:0

R:227 G:21 B:20

E31514

C:44 M:55 Y:91 K:65
R:79 G:59 B:20
4F3B14

Figure 11. Branded colors
C:4 M:0 Y:89 K:0

R:254 G:235 B:23

FEEB17

\section{Museum space organization concept}

For a museum, the most important elements are exhibits that should attract visitors and motivate them. Therefore, we are looking for a rethinking of the museum as an institution that takes into account the opinion and worldview of its visitors. That is why the offered exhibition stands were designed to create different departments. One of the rooms is the Karanka room: an archaeological exhibition that will make the culture of Karanka accessible with its culture and socio-economic organization. Figure 12 shows the developed museum booklet and an example of the graphic design of the stand based on the Inca iconography.
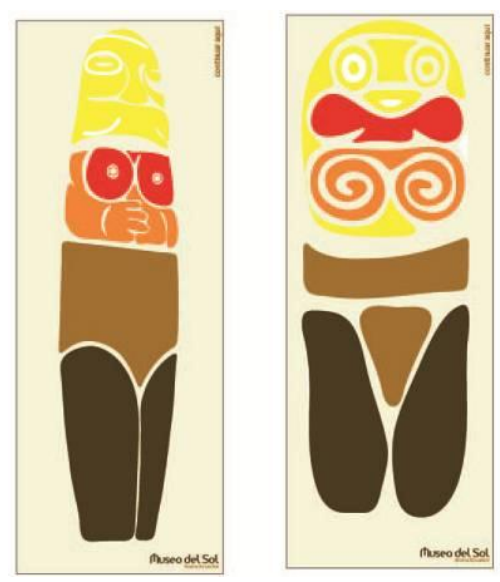
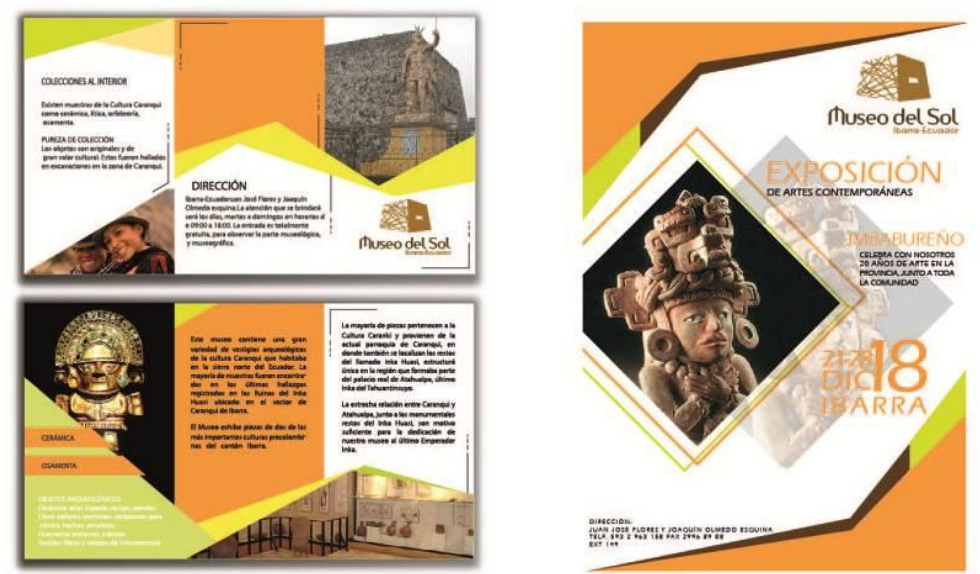

Figure 12. Branded graphic products

When designing the interior, it is also necessary to consider protection against theft, fire, humidity, temperature, and sunlight, which can damage the objects that are exposed. The movement of visitors is determined according to showcases, panels, texts, or colors of works.

Showcases are presented in the form of glass cabinets for the safe display of objects. This makes it easier to observe each of the elements, in some cases, they help organize an excursion along the route. There are different types of display cases, which must be selected following the characteristics of the object (Shcherbina, 2011; Sanchez, Abbasov, 2017; Abbasov, Sanchez, 2018). A horizontal flat showcase is used for storing and displaying exhibits in a horizontal direction, such as books, paper, ceramics, textiles, and others. Vertical cabinet: used for displaying large

Abbasov, I., \& Sanchez, C. L. (2020). Design features of the Inca museum of culture. International Research Journal of Engineering, IT \& Scientific Research, 6(5), 1-12. https://doi.org/10.21744/irjeis.v6n5.970 
exhibits or a set of small objects. Figure 13. the concept of the exposition of one of the halls of the museum and a corporate information stand are presented.
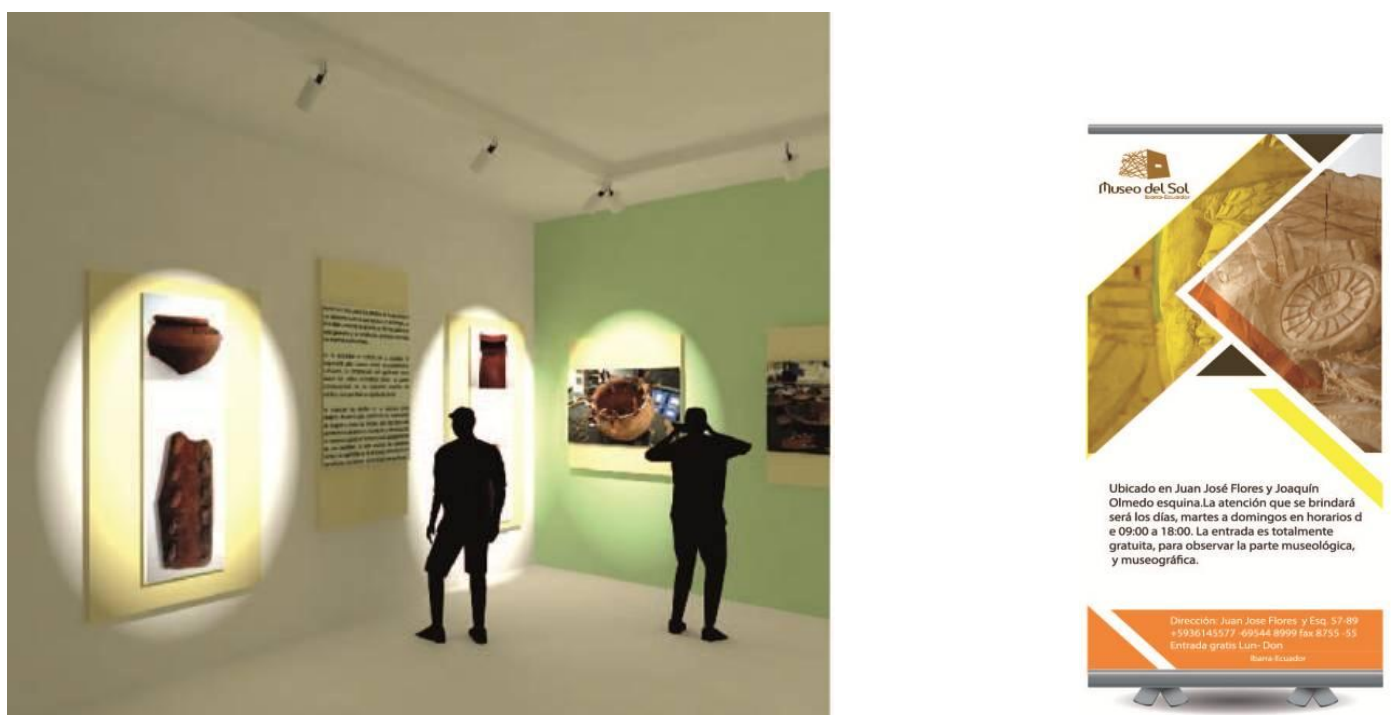

Figure 13. Indoor exhibition and information stand

\section{Conclusion}

The development of a new design concept for the Museum of the Sun (Museo del Sol) was carried out based on analysis and collection of information, which allowed to give a new, modern and cultural image to the brand. The components of the new brand of the museum were proposed, it allows identifying the various compositional modules, typology, chromatic and semantic codes used in the exhibits, combining all these elements concerning the business image of the museum. As a result of the application of trends and modern technologies in the field of design engineering, interest in the culture of the Incas can be increased by local visitors and foreign tourists.

\section{Conflict of interest statement}

The authors declared that they have no competing interest.

\section{Statement of authorship}

The authors have a responsibility for the conception and design of the study. The authors have approved the final article.

\section{Acknowledgments}

We are grateful to two anonymous reviewers for their valuable comments on the earlier version of this paper. 


\section{References}

Abbasov, I.B. \& Sanchez, K. (2018). Design of the museum space of the Inca culture "Museo del Sol". Culture and Art. 8. 40-53 (in russian)

Airy, D. (2011). Logotype and corporate identity. Designer manual. Sankt Peterburg. Peter, 208 (in russian).

Alvarez, C. \& Sanchez, J. (2002). The Great Museums. Madrid-Spain. Editorial Dastin Export, 287.

Brito Mario. (2011). Ancestral Iconography, Ecuador, 192.

Carelli, M. D., Conway, L. E., Oriani, L., Petrović, B., Lombardi, C. V., Ricotti, M. E., ... \& Grgić, D. (2004). The design and safety features of the IRIS reactor. Nuclear Engineering and Design, 230(1-3), 151-167. https://doi.org/10.1016/j.nucengdes.2003.11.022

Carlos, A. (2004). Iconography of the ancestors of Imbabura, Ecuador, 209.

Dzikevich, S.A. (2004). The aesthetics of advertising. Moscow. Gardariki. 232 (in russian).

Golovleva, E.L. (2005). Basics of advertising. M.: Moscow. Humanitarian Institute. 128 (in russian).

Huang, Z., \& Benyoucef, M. (2013). From e-commerce to social commerce: A close look at design features. Electronic Commerce Research and Applications, 12(4), 246-259. https://doi.org/10.1016/j.elerap.2012.12.003

Inca Culture (2013). [[Electronic resource] // Studio website: History of cultures Access mode: http://resumencorto.blogspot.ru/2013/08/resumen-corto-de-la-cultura-inca.html"

Iturralde, P., Mogrovejo, P. (2004). Dual and reciprocal: the visual communication of Ecuador, Quito-Ecuador, 135.

Jorge, S. (2005). Resistance of the Kingdom of Quito against the expansion of the Incas; History of Ecuador, -2005. II, 129.

Milla, Z. (1990). Introduction to the semiotics of pre-Columbian Andean architecture, Lima Peru, 89.

Oswaldo, G.R. (2014). Pre-Columbian iconography and its application in folklore, 207.

Salomons, O. W., van Houten, F. J., \& Kals, H. J. J. (1993). Review of research in feature-based design. Journal of manufacturing systems, 12(2), 113-132. https://doi.org/10.1016/0278-6125(93)90012-I

Sanchez, K.L., Abbasov, I.B. (2017). Design concept of the museum space of the Inca culture. In the Proceeding: World Science: Problems and innovations. Collection of articles of the XIV International Scientific and Practical Conference: 2, 276-279 (in russian).

Sauermann, H., \& Roach, M. (2013). Increasing web survey response rates in innovation research: An experimental study of static and dynamic contact design features. Research Policy, 42(1), 273-286. https://doi.org/10.1016/j.respol.2012.05.003

Scott, C.A. (2007). "Branding Museums" in Museum. Marketing \& Rentschler R, Amsterdam, 285.

Shcherbina, A.V. (2011). Museum design: teaching aid. - Togliatti: Togliatti State University, 68 (in russian).

Stallabrass, J. (2014). Branding of the museum. History of Art, 265.

Wu, Z., Lin, D., \& Zhong, D. (2002). The design features of the HTR-10. Nuclear Engineering and Design, 218(13), 25-32. https://doi.org/10.1016/S0029-5493(02)00182-6

Zuidema, R. T. (1986). Civilisation Inca аи Сиzсо (Vol. 14). Presses Universitaires de France-PUF.

Abbasov, I., \& Sanchez, C. L. (2020). Design features of the Inca museum of culture. International Research Journal of Engineering, IT \& Scientific Research, 6(5), 1-12. https://doi.org/10.21744/irjeis.v6n5.970 